\title{
THE IMPACT OF INDEPENDENT DIRECTOR ON BOARD OF
}

\section{DIRECTORS ON FIRM'S PERFORMANCE}

\section{EVIDENCE FROM INDONESIA}

\section{MAHARANI PUTRI SEKAR. N}

Faculty of Economy and Business, Universitas Indonesia

\begin{abstract}
Independent directors and ownership concentration are two important things at corporate governance that affects the firm performance. Independent Directories considered capable to improve the performance of the company as it can represent all shareholder interests, especially to the company whose ownership still concentrated. Indonesia is one of the countries where the structure company ownership is still highly concentrated and vulnerable to inter-conflict shareholders. Currently, Indonesia has a regulation on liability a public company to have at least one independent director within the ranks Board of Directors. The regulation is issued by the Indonesia Stock Exchange (IDX) on 2014. This study aims to determine the impact of the existence of the independent director on firm performance in Indonesia. This study used 370companies listed on the IDX as research samples with observation period5 years from 2012 to 2016. Using the panel data regression method, this study found that independent directors had no influential effect on firm performance. This study also found that ownership concentration has no independent board of directors who influence on firmperformance.
\end{abstract}

KEYWORDS: Independent Director, Ownership Concentration, Firm Performance \& Corporate Governance

Received: Aug 03, 2018; Accepted: Aug 23, 2018; Published: Oct 01, 2018; Paper Id.: IJBMROCT20185

\section{INTRODUCTION}

One of the important issues that exist in corporate governance is the representation of independent directors within the ranks of the BOD. This issue has become a global trend and many countries are already implementing board dependency reform of corporate governance. Different countries have also issued recommendations on the structure of the board of directors, particularly regarding the proportion of independent directors in a company(Crespi-Cladera \& Pascual-Fuster, 2014). Besides, the capital market regulator usually asks the company to meet the minimum percentage of independent directors who served on the board of directors(OECD, 2015).

An independent director of corporate governance is required to help top management to resolve the agency's problems (Fama \& Jensen, 1983b). One of the most common agency problems in companies is the conflict between shareholders, especially in family-controlled companies(Shleifer \& Vishny, 1986). The directors must be independent of managementin order for the director to be able to supervise the company effectively and reduce the conflict between shareholders(Fama \& Jensen, 1983a). Therefore, independent directors are required to address issues in corporate governance. 
In addition to the Agency Theory mentioned that the existence of independent directors will increase the dependency and performance of the company(Fama \& Jensen, 1983a; Jensen \& Meckling, 1976). An independent director is expected to be an important governance mechanism to supervise management behavior and reduce agency costs(Fama $\&$ Jensen, 1983a). Some literature also suggests that independent directors and concentration of ownership are the two most important things in corporate governance that affect company'sperformance(Adams, Hermalin, \& Weisbach, 2010; Bozec, 2005). (Peng, Zhang, \& Li, 2007)argues that the assumption of agency theory is universal so that the advantages and disadvantages of the existence of independent directors are relevant for all economic conditions.

To overcome the agency problem in corporate governance is by issuingthe regulations relating to independent directors within a country. A wide range of research has been done in both the one-tier countries and the two-tier countries. But until now, the results of research on the influence of independent directors on performance still vary.

A lot of research has been done to recognize the impact of independent directors on the firm performance in countries that adopt the one-tier system. Research on the impact of independent directors in two-tier system has also been done but the numbers are not many. Several studies have been conducted to determine the impact of independent directors on company performance in China, Russia and South Africa. Independent directors have an influence on firm performance in China(Li, Lu, Mittoo, \& Zhang, 2015). Other studies have shown that independent directors have a significant positive effect on the performance of Chinese companies, and their influence is much greater for state enterprises than private enterprise firms(Liu, Miletkov, Wei, \& Yang, 2015). The proportion of independent directors also affects the performance of mining companies in South Africa(Semosa, 2013). However, the independent director has no effect on the performance of oil and gas companies in Russia(Orazalin, Makarov, \& Ospanova, 2014).

Indonesia is a country where the Management of its Limited Liability Company uses a two-tier system that refers to the Law no. 40 on 2007 regarding Limited Liability Company. The law states that there is a separation of functions between the board of commissioners and the board of directors, where the board of directors is more in charge of running the company while the board of commissioners is more supervisory to the company. This is, of course, differ from many other countries that embrace one-tier system. Therefore, this study focuses on examining the independent director in terms of two-tier terms.

Indonesia is also one of the many countries that have companies with concentrated ownership. Based on the results of a survey conducted by the OECD using a sample data of 186 companies listed on the IDX, 70\% of ownership are held by controlling shareholder and 58\% of companies are family-controlled (2006-2007)(OECD, 2015). According to the Organization for Economic Co-operation and Development (OECD), companies that have a concentrated ownership structure will increase the horizontal agency problem between controlling shareholder and minority shareholder. This is what causes minority shareholder positions to be very poor and vulnerable to have conflicts with controlling shareholders(Daniel, 2003). Investor protection is very important in Indonesia, due to the potential for takeover of minority shareholder function by controlling shareholder(Daniel, 2003).

In 2014, Indonesia Stock Exchange (IDX) has issued Circular Letter Number I-A- Decree of the Board of Directors of PT IDX Number KEP-0001/BEI/01-2014 on 2014 which regulates all listed money issuers. The Regulation explains that all companies listed on the Stock Exchange must have independent directors at least 1 (one) in the board of directors. This regulation shall enter into force on January 30th, 2014 and shall be followed by all companies listed on the Stock Exchange. 
Previously, there has been research in Indonesia that sees the influence of independent commissioners and firm performance(Prabowo \& Simpson, 2011). The study wants to see the influence of independent commissioners on firm performance. This is what motivates the author to conduct research to see the effect of independent directors on the firm performance in Indonesia, and see if the IDX rules issued in 2014 affect the firm performance in Indonesia. It is hopeful that this research can contribute to research on the impact of independent directors on the firmperformance whose holdings are still concentrated.

Based on the above description, the purpose of this study is to answer the following questions:

- Does the independent director have a positive effect on the performance of the company in Indonesia?

- Does the ownership concentration weaken the positive influence of independent directors on the performance of firms in Indonesia?

The empirical contribution of this research is to provide an extension of insight in the field of corporate governance related to the impact of independent directors on the firm performance, especially in companies with concentrated ownership.

\section{Impact of Independent Director to Firm Performance}

Various studies have been conducted to determine the effect of independent directors on company performance. Duchin, Marsusaka, Dan Ozbas (2010) conducts research related to regulatory changes that require companies to increase the number of independent directors on firm performance. Firm performance is measured through ROA, Tobin's Q, and stock return values. The study used data from 1996 to 2005 with a total of 15,820 observations with a total of 2,897 companies and the analysis was done by regression method. The result of this study is the impact of independent directors on firm performance depends on the firm information cost. If the information cost is low, then the addition of an independent director to the board of directors will improve the performance of the company. On the other hand, if the information cost is high, then the addition of independent directors to the board of directors will actually worsen the performance of the company(Duchin, Matsusaka, \& Ozbas, 2010).

Jongmoo Jay Choi, Sae Woon Park, and Sean Sehyun Yoo have been conducting research on the influence of independent directors on corporate performance in South Korea during the Asian financial crisis. Company performance is measured by Tobin's Q value and research is used with panel data methods. The results of this study indicate that the presence of independent directors has a positive impact on the firm performance after the crisis(Jongmoo Jay Choi, Sae Woon Park, 2006).

Sanjai Bhagat and Bernard Black (2002) conducts a study of independent director relationships and long-term corporate performance. The study is conducted using an American public company dominated by an independent director. The data used are 1991 data of 934 companies. Company performance is measured by Tobin's Q, ROA, and market stock price returns. The study was conducted using OLS regression method. The result of this research is the change of the number of independent directors if the company has a poor performance, in other words, if the company is experiencing problems in profitability, then the company will increase the number of independent directors. However, there is no evidence to suggest whether the strategy is capable of solving the firm profitability problem(Bhagat \& Black, 2002). 
Yu Liu et al. (2015) has proved that independent directors have a positive effect on the firm performance through research conducted in 2014. The study was conducted using the data of registered companies in China from 1999 to 2012. Total research observations amounted to 16.999 with a total of 2057 companies by using a panel regression method. Company performance is measured by ROA and ROE. The result of this study is that independent directors have a positive impact on the performance of government controlled companies(Liu et al., 2015).

Nurlan Orazalin, Rashid Makarov, and Madina Ospanova (2014) conduct the research on the influence of board size and independent directors of oil and gas companies in Russia. The study used the 20 largest oil and gas companies in Russia with a total of 78 total observations. The study focused on 2009 and 2012 after Russia passed the Economic crisis. Company performance is measured by asset growth, equity to asset ratio, ROA, ROE, current asset ratio, and quick ratio. The results of this study indicate that the independent director does not affect the performance of the company(Orazalin et al., 2014). Selilo Semosa (2013) has also conducted research on the impact of independent directors' proportion to the performance of mining companies in South Africa. The result of this study is that independent directors have a positive impact on firm performance in South Africa represented by EVA company performance variables(Semosa, 2013).

Based on the theory of independent director in CG along with some previous research results, the hypothesis in this study is:

H1: Independent Director has a positive impact on the Firm Performance

\section{The Impact of Ownership Concentration of the Firm Performance}

Good Corporate Governance (GCG) relies on a combination of rights protection for investors and appropriate concentration of ownership. The concentration of ownership is higher in less developed countries where the rights of shareholders are not protected due to the absence of laws governing the ownership structure. This is the reason why the ownership structure and performance of the company is one of the benchmarks of an effective corporate governance system(Mandacı \& Gumus, 2010).

On concentrated ownership, the level of likelihood of conflict between shareholders is greater and will result in high cost(Claessens, 1997). Blockholder can reduce the performance and value of the company(Edmans, 2014). The higher the concentration of ownership, then the firm performance will decrease(Gursoy \& Kursat, 2002). Firm performance based on accounting valuation will decrease if the concentration of ownership is greater, but, otherwise, market performance will be better if the concentration of ownership is greater(Gursoy \& Kursat, 2002). The performance of new companies will improve when the concentration of ownership is low(Arosa, Iturralde, \& Maseda, 2010). The ownership structure of the company must spreadin order for the company to be able to increase the company's profit(Demsetz, 1983). Other studies suggest that the more spread (not concentrated) ownership, then the ownership of the company has a positive relationship with the firm performance(Anderson \& Reeb, 2003; Pindado, Requejo, \& Torre, 2008; Thomsen \& Pedersen, 2000)

Based on the theory of ownership concentration in CG along with some previous research results, the hypothesis in this study is:

H2: Concentrated Ownership weakened the positive impact of Independent Director to the Firm Performance 


\section{METHOD OF THE RESEARCH}

\section{Selection Method and Data Obtained}

This study uses a variety of data derived from the financial statements of companies that have been listed on the Stock Exchange from 2012 to 2016. Data can also be obtained from the financial statements that usually use the official website of each company. Eikon Thomson Reuters is also used to retrieve other data that cannot be obtained in the financial statements. The study used a variety of non-financial companies in Indonesia mentioned in IDX. The broad data of the director, company age, and the size of the board of directors obtain from the annual report of each company. While other data, the value of ROA, ROE, assets, and leverage are obtained from Thomson Reuters. Here are the requirements that must be separated from the company to be included in theresearch sample:

- The Companies are engaged in the non-financial sector listed on the Indonesia Stock Exchange during the period 2012-2016

- $\quad$ The Companies publish its annual report and financial report during the period 2012-2016

Based on the results of sample selection in accordance with the requirements of the study, then the company is ready to be tested from 2012-2016 is as many as 370 companies. Thus, total observations for panel data amounted to 1850 observations.

\section{Operational Research Definition}

The following is the operational definition of this research.

\section{Independent Variable}

The independent variable is the independent variable which is not affected by other variables. This time the study used two independent variables, for example, the percentage of the proportion of independent directors in a company and the percentage of the proportion of independent directors of the owners.

\section{Percentage Variable of Independent Director in a Company}

This variable is used to calculate the percentage of independent directors within each company listed on the IDX. Here is the percentage formula of independent directors:

$$
\% \text { Independent director }=\frac{\Sigma \text { Independent director }}{\Sigma B O D \text { in a company }}
$$

\section{Percentage Variable of Ownership}

This variable is used to see the greatest ownership within a company. Research is conducted by Berle-Means (1932) implies that widespread ownership may affect company performance. On the other hand, the results of $\mathrm{P}$ Kapopoulos (2006) research indicate that the more concentrated ownership structure has a positive correlation with the performance of larger companies.

$\%$ The largest ownership $=$ shareholder with the largest ownership

\section{Dependent Variable}

The dependent variable is an influenced variable or a variable bound to another variable. This study uses two 
dependent variables, namely Return on Assets (ROA) and Returns on Equity (ROE).

\section{Return on Assets (ROA)}

Returns on Assets(ROA) is used to measure company performance. According to Munawir (2002), ROA can describe how many companies get the results of the company's financial resources. The value of ROA depends on the sector and industry of each company. The ROA value used is the company's ROA from 2012-2016. ROA data is obtained from Eikon Thomson Reuters.

\section{Return on Equity (ROE)}

Return on Equity (ROE)can be used to assess the rate of return the company to generate profits from the company's capital. The ROE value used is the company's ROE from 2012-2016. ROE data obtained by Eikon Thomson Reuters.

\section{Control Variable}

In this research, we will use four control variables, namely company size, company age, board size, and leverage.

\section{Company Size}

There have been several studies conducted to show that company size affects company performance. The size of the company plays an important role on the profitability of the company(Lee, 2009). Companies on a large scale have higher performance compared to small scale companies (Ozgulbas, 2010). Other studies have also been conducted by Vijayakumar and Tamizhselvan (2010) where the results show that there is a positive relationship between company size and profitability. It differs from the results of research Becker et al. (2010) where the results of the study did not show any relationship between company size and company performance. This study will use the company size calculations used by(Bhagat \& Black, 2002).

$$
\text { Company size }=\log (\text { asset })
$$

\section{Company Age}

Research on the relationship of a company's performance to the company age has been done a lot. Some studies say that the age of the company can damage, the firm performance, namely ROA, Tobin's Q, and sales growth(Loderer \& Waelchli, 2009). This is because the company will experience aging problem(Loderer \& Waelchli, 2009). On the other hand, another study mentions that the older a company the productivity will increase, but the profits will decrease(Majumdar, 1997). The results of Anderson and Reeb (2003) found that the firm age log result (firm age) results in the family company does not affect the performance of the company. While Coad, Segarra, and Teruel (2010) actually found that the company will be better in terms of productivity and profit with the age of the company. This study will use the company formula from Anderson and Reeb's research (2003).

$$
\text { Company age }=\log (\text { firm age })
$$

\section{Board size}

The size of the board of the company (BOD) is considered to have an effect on the performance of the company. Lipton and Lorsch (1992), Jensen (1993), Yermack (1996), mentioned that the smaller board size will contribute more to the company's success. As with Pleffer (1972), Klein (1998) argues that companies with large board sizes will be able to improve the firm performance. Dalton et al. (1999) mentions that companies with large board sizes have better corporate 


\section{Leverage}

In research conducted by Safieddine and Titman (1999) mentioned that leverage can help companies to remain independent because company managers will be more committed. Research which is conducted by L Weill (2003) get results where leverage affects the performance of companies in France and Germany, but leverage does not affect the performance of companies in Italy. The formula for leverage is as follows:

$$
\text { leverage }=\frac{\text { total debt }}{\text { total equity }}
$$

\section{Data Analysis Method}

In accordance with the purpose of research that has been described previously, then this study using 6 (six) models. This is because to know the influence of independent directors in the firm performance and the impact of independent directors on the firmperformance with concentrated ownership before and after the IDX rules are stipulated. To determine the impact of independent directors on firm performance, then the following regressions are used:

\section{ROA 1 Model $=$}

$$
R O A_{i t}=\alpha+\beta P R O P D I_{i t}+\gamma S I Z E_{i t}+\gamma A G E_{i t}+\gamma B O A R D_{i t}+\gamma L E V_{i t}+\varepsilon_{i t}
$$

\section{ROE 1 Model $=$}

$$
R O E_{i t}=\alpha+\beta P R O P D I_{i t}+\gamma S I Z E_{i t}+\gamma A G E_{i t}+\gamma B O A R D_{i t}+\gamma L E V_{i t}+\varepsilon_{i t}
$$

To determine the impact of independent directors on the firmperformance with concentrated ownership, the following regressions are used:

\section{ROA 2 Model =}

$$
R O A_{i t}=\alpha+\beta P R O P D I_{i t}+\beta P R O P D I_{i t} * O C_{i t}+\beta P R O P D I_{i t} * \beta D U M M Y R E G_{i t}+\gamma S I Z E_{i t}+\gamma A G E_{i t}+
$$
$\gamma B O A R D_{i t}+\gamma L E V+\varepsilon_{i t}$

\section{ROE 2 Model $=$}

$$
R O E_{i t}=\alpha+\beta P R O P D I_{i t}+\beta P R O P D I_{i t} * O C_{i t}+\beta P R O P D I_{i t} * \beta D U M M Y R E G_{i t}+\gamma S I Z E_{i t}+\gamma A G E_{i t}+
$$
$\gamma B O A R D_{i t}+\gamma L E V+\varepsilon_{i t}$

To determine the impact of independent directors on company performance before and after the regulation of IDXis stipulated, the following regressions are used:

\section{ROA O Model $=$}

$$
R O A_{i t}=\alpha+\beta P R O P D I_{i t}+\beta P R O P D I_{i t} * \beta D U M M Y R E G_{i t}+\gamma \mathrm{SIZE}_{i t}+\gamma \mathrm{AGE}_{i \mathrm{it}}+\gamma \mathrm{BOARD}_{\mathrm{it}}+\gamma \mathrm{LEV}_{\mathrm{it}}+\varepsilon_{\mathrm{it}}
$$

\section{ROE 0 Model $=$}

$$
\mathrm{ROE}_{i \mathrm{t}}=\alpha+\beta \mathrm{PROPDI}_{\mathrm{it}}+\beta \mathrm{PROPDI}_{\mathrm{it}} * \beta \mathrm{PUMMYREG}_{\mathrm{it}}+\gamma \mathrm{SIZE}_{\mathrm{it}}+\gamma \mathrm{AGE}_{\mathrm{it}}+\gamma \mathrm{BOARD}_{\mathrm{it}}+\gamma \mathrm{LEV}_{\mathrm{it}}+\varepsilon_{\mathrm{it}}
$$


where:

- $\alpha=$ constans

- $\quad R O A_{i t}=$ firm observation iyear tfrom dependent variable ROA

- $R O E_{i t}=$ firm observation iyear tfrom dependent variable $\mathrm{ROE}$

- $\quad P R O P D I_{i t}=$ firm observation iyear tfrom independent variable independent director

- $O C_{i t}=$ firm observation iyear tfrom independent variable, greatest ownership within a company

- $\quad$ DUMMYREG $_{i t}=$ dummy variable for regulation, is 1 for post-regulation (2014-2016) and is 0 for pre-regulation (2012-2013)

- $\quad S I Z E_{i t}=$ firm observation iyear tfrom control variable, company's size

- $A G E_{i t}=$ firm observation iyear tfrom control variable, company's age

- $\quad B O A R D_{i t}=$ firm observation iyear tfrom control variable, company’s board size

- $\quad L E V_{i t}=$ firm observation iyear tfrom control variable, company's leverage

- $\quad \varepsilon_{i t}=$ error in regression

\section{ANALYSIS AND DISCUSSIONS}

\section{Descriptive Analysis}

Descriptive statistics for each of the research variables, for instance, independent directors (PROPDI), the largest ownership (OC), ROA, ROE, firm asset (ASSET), leverage (LEV), board/BOD size (BOARD), and company age (AGE) are as follows:

Table 1: Descriptive Statistical Result

\begin{tabular}{|c|c|c|c|c|c|}
\hline & Mean & Median & Maximum & Minimum & Std Dev. \\
\hline PROPDI & 0.137157 & 0.142857 & 0.666667 & 0 & 0.147410 \\
\hline OC & 0.503854 & 0.507000 & 0.847400 & 0.202800 & 0.211611 \\
\hline ROA & 0.041198 & 0.034565 & 0.149318 & -0.054305 & 0.063488 \\
\hline ROE & 0.084734 & 0.076631 & 0.280945 & -0.103183 & 0.120121 \\
\hline ASSET & 8.269021 & 8.267031 & 9.230449 & 7.301030 & 0.622194 \\
\hline LEV & 0.592914 & 0.424147 & 1.714540 & 0.000000 & 0.574976 \\
\hline BOARD & 0.607314 & 0.602060 & 0.845098 & 0.301030 & 0.159390 \\
\hline AGE & 1.467879 & 1.505150 & 1.681241 & 1.146128 & 0.170947 \\
\hline
\end{tabular}

Source: Author's Data Retrieval, 2017 (EViews 9)

The descriptive statistics in the Table 1 shows that the independent director variable as measured by the proportion of independent directors in the board of directors has an average value of $0.1371(13.71 \%)$ which indicates that the proportion of independent directors in Indonesian companies is still low. Independent director variables have a minimum value of $0(0 \%)$ which means there are companies that do not have independent directors and a maximum value of $0.666667(66.67 \%)$. Many companies in Indonesia do not have independent directors before the IDX regulations applied (2012-2013). While the value of the standard deviation of independent directors is $0.147410(14.74 \%)$. From the minimum value of ROA variable, it can be seen that there are Indonesian companies that suffered losses from assets owned. From the 
minimum value of the ROE variable, it can be seen that there are Indonesian companies experiencing losses from their own equity. Variable director ownership concentration (OC) has an average value of $0.503854(50.38 \%)$ which indicates many companies in Indonesia whose ownership structure is still highly concentrated that is more than $50 \%$.

\section{Regression Analysis}

Panel data regression has three different methods, namely Pooled Least Square, Fixed Effect Model, and Random Effec Model. After performing regression for each model on fixed effect and random effect, then the next step is to choose what method suitable for each model. Chow test, Hausman test, and Lagrange Multiplier test need to be done to choose the most appropriate regression method for each research model.

Table 2: Summary of the Best Test Model

\begin{tabular}{|l|c|c|c|c|c|c|c|}
\hline $\begin{array}{c}\text { Best Regression } \\
\text { Model Testing }\end{array}$ & $\begin{array}{c}\text { Model 1 } \\
\text { ROA }\end{array}$ & $\begin{array}{c}\text { Model 1 } \\
\text { ROE }\end{array}$ & $\begin{array}{c}\text { Model 2 } \\
\text { ROA }\end{array}$ & $\begin{array}{c}\text { Model 2 } \\
\text { ROE }\end{array}$ & $\begin{array}{c}\text { Model 0 } \\
\text { ROA }\end{array}$ & $\begin{array}{c}\text { Model 0 } \\
\text { ROE }\end{array}$ & Conclusion \\
\hline $\begin{array}{l}\text { Chow Test: p-value } \\
\text { (Cross-Section F) }\end{array}$ & $0.0000^{* * *}$ & $0.0000^{* * *}$ & $0.0000^{* * *}$ & $0.0000^{* * *}$ & $0.0000^{* * *}$ & $0.0000^{* * *}$ & $\begin{array}{l}\text { Fixed Effect } \\
\text { Model }\end{array}$ \\
\hline $\begin{array}{l}\text { Hausman Test: } \\
\text { p-value (Cross- } \\
\text { Section Random) }\end{array}$ & $0.0000^{* * *}$ & $0.0000^{* * *}$ & $0.0000^{* * *}$ & $0.0000^{* * *}$ & $0.0000^{* * *}$ & $0.0000^{* * *}$ & $\begin{array}{l}\text { Fixed Effect } \\
\text { Model }\end{array}$ \\
\hline
\end{tabular}

*** Significant Level at $1 \%$

** Significant Level at 5\%

* Significant Level at $10 \%$

Source: Author's Data Retrieval, 2017 (EViews 9)

From the Table 2 above shows that all models use fixed effect model as the best model.

\section{Classical Assumption Test}

In this study, the normality test for each observation variable using skewness and kurtosis. Skewness is a measure of the degree of symmetry of the probability distribution. For normal data it generally has zero skewness value. Kurtosis describes the height of the probability distribution of a data. Normal distribution can be seen from the value of kurtosis approaching three. On this research, the data is normal distributed with skewness value close to zero and kurtosis value close to 3 .

The multicollinearity test is used to test whether there is a correlation between independent variables. The multicollinearity test is performed using the correlation function in Eviews 9. If all correlation values are $<0.8$, then there is no multicollinearity. In this study, the correlation between independent variables $<0.8$ so that no multicollinearity occurs.

Heteroskedasticity test was used to test whether there were outliers in the study. A good research model is a homoscedastic model (with fixed variance and residuals) and no heteroscedasticity. Heteroscedasticity was tested using RSquared cross-section weighted and R-Squared no weighting. If the value of R-Squared cross-section weighted > RSquared no weighting then heteroscedasticity occurs. Heteroskedasticity test is done to all models because it uses fixed effect model method which previously been shown in Table 4-11. In this study, all models have $\mathrm{R}^{2}$ Cross-section weighted $>\mathrm{R}^{2}$ no weighting, so all models experience heteroscedasticity. In this study, all independent variables are not significant and standard error value $<2$. Nachrowi (2006), if standard error of free variable $<2$ and significant, then indicate that the heteroscedasticity that happened also very small. 
The autocorrelation test in this study used Durbin-Watson test (DW-test). The DW-test will be compared to the limit value of the DW-table that can be adjusted by the number of observations $(\mathrm{T})$ and the independent variable number (K). This study used $\mathrm{T}=1850$ and $\mathrm{K}=5$ for model $1, \mathrm{~T}=1850$ and $\mathrm{K}=6$ for model 2 , and $\mathrm{T}-1850$ and $\mathrm{K}=4$ for after regulation. The autocorrelation test is performed for all models in which each model uses the fixed effect model method that has been shown in Table 4-11. In this study, all models have $\mathrm{DW}<\mathrm{dU}$ values so that there is a negative autocorrelation in ROA 1 Model, ROE 1 Model, hesitant in ROE 1 Model and ROE 2 Model, and negative on model after regulation. However, according to Nachrowi (2006), he states that the method of fixed effect model does not require the assumption of free model from autocorrelation series.

\section{Hypothesis Test}

After getting the best method for each model, then the next step is to test the hypothesis. Hypothesis test is done to know the significant influence of the independent variable of the dependent variable. The six models in this research use fixed effect model. Hypothesis test will use three methods which are T test and F test.

F test is used to determine the effect of independent variables simultaneously to the dependent variable with significant equal to 0.05 . If the value is significant $<0.05$, then it can be stated that all independent variables have an effect simultaneously on the dependent variable and vice versa. Here are the results of the F test for six research models:

Table 3: F Test on Every Model

\begin{tabular}{|c|c|c|l|}
\hline Model & Significant Level & Conclusion & \multicolumn{1}{|c|}{ Explanation } \\
\hline Model 1 ROA & 0.000000 & $\begin{array}{c}0.000000<0.05 \rightarrow \\
\mathrm{H}_{0} \text { rejected }\end{array}$ & $\begin{array}{l}\text { Independent variable have } \\
\text { have an effect simultaneously } \\
\text { on the dependent variable }\end{array}$ \\
\hline Model 2 ROA & 0.000000 & $\begin{array}{c}0.000000<0.05 \rightarrow \\
\mathrm{H}_{0} \text { rejected }\end{array}$ & $\begin{array}{l}\text { Independent variable have } \\
\text { have an effect simultaneously } \\
\text { on the dependent variable }\end{array}$ \\
\hline Model 1 ROE & 0.000000 & $\begin{array}{c}0.000000<0.05 \rightarrow \\
\mathrm{H}_{0} \text { rejected }\end{array}$ & $\begin{array}{l}\text { Independent variable have } \\
\text { have an effect simultaneously } \\
\text { on the dependent variable }\end{array}$ \\
\hline Model 2 ROE & 0.000000 & $\begin{array}{c}0.000000<0.05 \rightarrow \\
\mathrm{H}_{0} \text { rejected }\end{array}$ & $\begin{array}{l}\text { Independent variable have } \\
\text { have an effect simultaneously } \\
\text { on the dependent variable }\end{array}$ \\
\hline Model 0 ROE & 0.000000 & $\begin{array}{c}\text { r.000000 }<0.05 \rightarrow \\
\mathrm{H}_{0} \text { rejected }\end{array}$ & $\begin{array}{l}\text { Independent variable have } \\
\text { have an effect simultaneously } \\
\text { on the dependent variable }\end{array}$ \\
\hline
\end{tabular}

Source: Author's Data Retrieval, 2017 (EViews 9)

Table 3 shows that all independent variables in this study have a significant impact on firm performance.

T-test is done to know how significant influence of independent variable to dependent variable. T-Test is done by testing each independent variable separately to the dependent variable. If Probability value is smaller than the error rate $(\alpha)$, then the independent variables significantly influence the dependent variable, and vice versa. 
Table 4: Summary of Regression of Hypothesis 1

\begin{tabular}{|c|c|c|c|c|c|c|}
\hline \multirow{2}{*}{$\begin{array}{c}\text { Independent } \\
\text { Variable }\end{array}$} & \multicolumn{2}{|c|}{ Dependent Variable ROA } & \multicolumn{3}{c|}{ Dependent Variable ROE } \\
\cline { 2 - 7 } & Coef & t-stat & Prob 1-tail & Coef & t-stat & Prob 1-tail \\
\hline C & 0.5372 & 5.6121 & $0.0000^{* * * *}$ & 0.9849 & 5.0398 & $0.0000^{* * * *}$ \\
\hline PROPDI & -0.0041 & -0.4025 & 0.3437 & -0.0074 & -0.3600 & 0.3594 \\
\hline LEV & -0.0173 & -5.1018 & $0.0000^{* * * *}$ & -0.0473 & -6.8028 & $0.0000^{* * * *}$ \\
\hline BOARD & -0.0122 & -0.7932 & 0.2139 & -0.0361 & -1.1461 & 0.1259 \\
\hline ASSET & 0.0234 & 2.8114 & $0.0025^{* * * *}$ & 0.0733 & 4.2993 & $0.0000^{* * *}$ \\
\hline AGE & -0.4577 & -9.4987 & $0.0000^{* * * *}$ & -0.9914 & -10.078 & $0.0000^{* * *}$ \\
\hline
\end{tabular}

***Significant Level at $1 \%$

**Significant Level at 5\%

*Significant Level at $10 \%$

Source: Author's Data Retrieval, 2017 (EViews 9)

Based on the regression result using fixed effect method as can be seen in the Table 4, it is found that independent directors have no effect on ROA and ROE of the company. While the leverage control variables and company age are negatively affect the performance of the comapny's ROA and ROE at a confidence level of $1 \%$. For company size control variables, it positively affects the firm performance ROA and ROE at $1 \%$ confidence level. While the control variables of the board size do not affect the performance of ROA and ROE.

Table 5: Summary of Regression of Hypothesis 2

\begin{tabular}{|l|c|c|c|c|c|c|}
\hline \multirow{2}{*}{$\begin{array}{c}\text { Independent } \\
\text { Variable }\end{array}$} & \multicolumn{3}{|c|}{ Dependent Variable ROA } & \multicolumn{2}{c|}{ Dependent Variable ROE } \\
\cline { 2 - 7 } & Coef & t-stat & Prob 1-tail & coef & t-stat & Prob 1-tail \\
\hline C & 0.4370 & 4.1962 & $0.0000^{* * * *}$ & 0.8464 & 3.9759 & $0.0000^{* * * *}$ \\
\hline PROPDI & 0.0018 & 0.0741 & 0.4704 & 0.0245 & 0.4875 & 0.3130 \\
\hline PROPDI*OC & 0.0292 & 0.7549 & 0.2252 & -0.0037 & -0.0474 & 0.4811 \\
\hline $\begin{array}{l}\text { PROPDI*DUMMY } \\
\text { REG }\end{array}$ & -0.0299 & -2.3568 & $0.0093^{* * *}$ & -0.0426 & -1.6411 & $0.0505^{* * *}$ \\
\hline LEV & -0.0172 & -5.0656 & $0.0000^{* * *}$ & -0.0473 & -6.7975 & $0.0000^{* * * *}$ \\
\hline BOARD & -0.0139 & -0.9026 & 0.1834 & -0.0389 & -1.2318 & 0.1091 \\
\hline ASSET & 0.0239 & 2.8696 & $0.0021^{* * * *}$ & 0.0737 & 4.3246 & $0.0000^{* * * *}$ \\
\hline AGE & -0.3912 & -7.0421 & $0.0000^{* * * *}$ & -0.8982 & -7.9099 & $0.0000^{* * * *}$ \\
\hline
\end{tabular}

*** Significant Level at $1 \%$

** Significant Level at $5 \%$

* Significant Level at $10 \%$

Source: Author's Data Retrieval, 2017 (EViews 9)

Based on regression result using fixed effect method as can be seen in the Table 5, it proves that ownership concentration has no impact on independent director relation to company's ROA performance. While company size control variables have positive impact on company performance ROA and ROE at $1 \%$ confidence level. For the control variable of company age and company leverage, it have negative effect to company performance of ROA and ROE at $1 \%$ confidence level. 
Table 6: Ringkasan Regresi Kinerja Setelah Regulasi

\begin{tabular}{|l|c|c|c|c|c|c|}
\hline \multirow{2}{*}{$\begin{array}{c}\text { Independent } \\
\text { Variable }\end{array}$} & \multicolumn{3}{|c|}{ Dependent Variable ROA } & \multicolumn{3}{c|}{ Dependent Variable ROE } \\
\cline { 2 - 7 } & Coef & t-stat & Prob 1-tail & coef & t-stat & Prob 1-tail \\
\hline C & 0.4382 & 4.2087 & $0.0000^{* * *}$ & 0.8463 & 3.9770 & $0.0000^{* * * *}$ \\
\hline PROPDI & 0.0173 & 1.2798 & 0.1004 & 0.0225 & 0.8140 & 0.1547 \\
\hline $\begin{array}{l}\text { PROPDI*DUMMYR } \\
\text { EG }\end{array}$ & -0.0303 & -2.3950 & $0.0083^{* * *}$ & -0.0425 & -1.6413 & $0.0025^{* *}$ \\
\hline LEV & -0.0173 & -5.1077 & $0.0000^{* * *}$ & -0.0473 & -6.8051 & $0.0000^{* * *}$ \\
\hline BOARD & -0.0142 & -0.9193 & 0.1790 & -0.0388 & -1.2315 & 0.1100 \\
\hline ASSET & 0.0238 & 2.8547 & $0.0022^{* * *}$ & 0.0737 & 4.3281 & $0.0000^{* * * *}$ \\
\hline AGE & -0.3911 & -7.0423 & $0.0000^{* * *}$ & -0.8982 & -7.9127 & $0.0000^{* * *}$ \\
\hline
\end{tabular}

*** Significant Level at $1 \%$

** Significant Level at 5\%

* Significant Level at $10 \%$

Source: Author's Data Retrieval, 2017 (EViews 9)

Based on the result of regression using fixed effect method as can be seen in the Table 6 , it is found that the existence of independent directors in the board of directors negatively impacts ROA and ROE after regulation is determined.

\section{CONCLUSIONS}

Research on the influence of independent directors on corporate performance has been largely done in one-tier countries, but research on two-tier countries are still rare. This is what motivates the author doing research. This study was conducted to try to see the effect of independent directors on company performance in Indonesia. Indonesia is a country that adopts a two-tier system, where each company separates the duties of the board of directors as the executor of the company's management and the duty of the board of commissioners as supervisor of the board of directors in carrying out the management duties of the company. In addition, Indonesia is one of the countries where there are still many companies whose ownership structure is still highly concentrated. Concentrated ownership, of course, affects the performance of companies in Indonesia.

The results of this study indicate that the proportion of independent directors on the board of directors has no impact on the firm performance. The results of this study also indicate that concentrated ownership of concentrated holdings has no impact on the impact of independent directors to ROA and ROE of the company. The existence of independent directors after the rules of IDX actually negatively impacts the firm performance both ROA and ROE.

\section{REFERENCES}

1. Adams, R. B., Hermalin, B. E., \& Weisbach, M. S. (2010). The Role of Boards of Directors in Corporate Governance: A Conceptual Framework and Survey. Journal of Economic Literature, 48(1), 58-107.

2. Anderson, R. C., \& Reeb, D. M. (2003). Founding-family ownership and firm performance: Evidence from the $S \& P 500$. Journal of Finance, 58(3), 1301-1328.

3. Arosa, B., Iturralde, T., \& Maseda, A. (2010). Ownership structure and firm performance in non-listed firms: Evidence from Spain. Journal of Family Business Strategy, 1(2), 88-96.

4. Bhagat, S., \& Black, B. (2002). The Non-Correlation Between Board Independence and Long Term Firm Performance The Non-Correlation Between Board Independence and Long-Term Firm Performance. Journal of Corporation Law, 27(2), 231273. 
5. Bozec, R. (2005). Boards of Directors, Market Discipline and Firm Performance. Journal of Business Finance \& Accounting, 32(9), 1921-1960.

6. Claessens, S. (1997). American Finance Association Corporate Governance and Equity Prices : Evidence from the Czech and Slovak Republics. The Journal of Finance, 52(4), 1641-1658.

7. Crespi-Cladera, R., \& Pascual-Fuster, B. (2014). Does the independence of independent directors matter? Journal of Corporate Finance, 28, 116-134.

8. Daniel, W. E. (2003). Bond Law Review Corporate Governance in Indonesian Listed Companies - A Problem of Legal Transplant Corporate Governance in Indonesian Listed Companies - A Problem of Legal Transplant, 15(1).

9. Demsetz, H. (1983). The structure of ownership and the theory of the fweshambriirm. The Journal of Law and Economics, 26(2), 391 .

10. Duchin, R., Matsusaka, J. G., \& Ozbas, O. (2010). When are outside directors effective? Journal of Financial Economics, 96(2), 195-214.

11. Edmans, A. (2014). Blockholders and Corporate Governance. Annual Review of Financial Economics, 6(1), 23-50. https://doi.org/10.1146/annurev-financial-110613-034455

12. Fama, E. F., \& Jensen, M. C. (1983a). Agency Problems and Residual Claims. The Journal of Law and Economics, 26(2), $327-349$.

13. Fama, E. F., \& Jensen, M. C. (1983b). Separation of Ownership and Control Author. The Journal of Law \& Economics, 26(2), $301-325$.

14. Gursoy, G., \& Kursat, A. (2002). Equity Ownership Structure, Risk Taking, and Performance An Empirical Investigation in Turkish Listed Companies. Emerging Markets Finance and Trade, 38(6), 6-25.

15. Jensen, M., \& Meckling, W. (1976). Theory of the firm: managerial behavior, agency costs, and ownership structure. The Economic Nature of the Firm, 283-303. https://doi.org/10.1017/CBO9780511817410.023

16. Jongmoo Jay Choi, Sae Woon Park, S. S. Y. (2006). The Value of Outside Directors : Evidence from Corporate Governance Reform in Korea. Forthcoming, Journal of Financial and Quantitative Analysis, (May).

17. Lee, J. (2009). Does size matter in firm performance? Evidence from US public firms. International Journal of the Economics of Business, 16(2), 189-203.

18. Li, K., Lu, L., Mittoo, U. R., \& Zhang, Z. (2015). Board independence, ownership concentration and corporate performanceChinese evidence. International Review of Financial Analysis, 41, 162-175.

19. Liu, Y., Miletkov, M. K., Wei, Z., \& Yang, T. (2015). Board independence and firm performance in China. Journal of Corporate Finance. Elsevier B. $V$.

20. Bishnoi, P. Emerging Trends And Practices In Corporate Governance And Corporate Social Responsibility.

21. Loderer, C., \& Waelchli, U. (2009). Firm Age and Performance. SGF Conference, (26450), 1-44.

22. Majumdar, S. K. (1997). The Impact of Size and Age on Firm-Level Performance: Some Evidence from India. Review of Industrial Organization, 12(2), 231-241.

23. Mandacl, P., \& Gumus, G. (2010). Ownership Concentration, Managerial Ownership and Firm Performance: Evidence from Turkey. South East European Journal of Economics and Business, 5(1), 57-66. 
24. Nachrowi, Djalal Nachrowi, Hardius Usman. 2006. Pendekatan Populer dan Praktis Ekonometruka untuk Analisis Ekonomi dan Keuangan, Lembaga Penerbit Universitas Indonesia, Jakarta.

25. OECD. (2015). Corporate Governance Factbook. OECD Corporate Governance Working Papers, (February), 1-76. Retrieved from http://www.oecd.org/daf/ca/CorporateGovernanceFactbook.pdf\%5Cnhttp://eprints.mdx.ac.uk/1581/

26. Orazalin, N., Makarov, R., \& Ospanova, M. (2014). Corporate Governance and Firm Performance in the Oil and Gas Industry of Russia. Wbiworldconpro.Com, 7(June), 1-12. Retrieved from http://www.wbiworldconpro.com/uploads/turkeyconference-2014/management/1402546852_422-Nurlan.pdf

27. Peng, M. W., Zhang, S., \& Li, X. (2007). CEO Duality and Firm Performance during China's Institutional Transitions. Management and Organization Review, 3(2), 205-225.

28. Pindado, J., Requejo, I., \& Torre, C. D. la. (2008). Does family ownership impact positively on firm value? Empirical evidence from Western Europe. Documento de Trabajo 02/08, 1-34.

29. Prabowo, M., \& Simpson, J. (2011). Independent directors and firm performance in family controlled firms: Evidence from Indonesia. Asian-Pacific Economic Literature, 25(1), 121-132.

30. Semosa, S. B. (2013). Impact of Board composition on performance in the South African Platinum Mining Industry.

31. Shleifer, A., \& Vishny, R. W. (1986). Large Shareholders and Corporate Control Author. Ournal of Political Economy, 94(3), $461-488$.

32. Thomsen, S., \& Pedersen, T. (2000). Ownership Structure and Economic Performance in the Largest European Companies. Strategic Management Journal, 21(6), 689-705. 